\title{
乾式コーティング技術を用いた電極活物質とイオン伝導材料の複合粒子の設計
}

\author{
仲村 英也 * \\ 大阪府立大学大学院工学研究科物質・化学系専攻化学工学分野, $\bar{T}$ 599-8531 堺市中区学園町 1-1.

\section{Design of Composite Particle of Electrode Active Material and Ionic Conductive Material by Means of a Dry Coating Technology}

\author{
Hideya NAKAMURA* \\ Department of Chemical Engineering, Osaka Prefecture University, 1-1 Gakuen-cho Naka-ku, Sakai 599-8531, Japan.
}

Received November 08, 2019; Revised December 12, 2019; Accepted December 16, 2019

\begin{abstract}
In this review, a dry coating technology to produce composite electrode of an all-solid-state battery is presented. Firstly, from the view point of the dry powder mixing, fundamental concept of the dry coating is reviewed. Secondly, our recent progress in the dry coating technology for cathode active material and sulfide solid electrolyte is presented. The dry coating technology is applied to produce the core-shell structure composite particle composed of cathode active material particle $\left(\mathrm{LiNi}_{1 / 3} \mathrm{Co}_{1 / 3} \mathrm{Mn}_{1 / 3} \mathrm{O}_{2}, \mathrm{NCM}\right)$ and sulfide solid electrolyte $\left(\mathrm{Li}_{3} \mathrm{PS}_{4}, \mathrm{LPS}\right)$. We demonstrate that by means of a dry coating process single NCM particle is uniformly coated with LPS without any breakage and attrition of the NCM particle, i.e., NCM@LPS core-shell particle is able to be successfully produced. Finally, performance of the half-cell prepared with NCM@LPS particles is presented. A composite cathode prepared with NCM@LPS particles exhibits much larger contact area between NCM and LPS, resulting in significant improvement of performance of an all-solid-state half-cell.
\end{abstract}

\section{KEY WORDS}

dry coating, core-shell composite particle, all-solid-state battery

\section{1 はじめに}

全固体リチウムイオン二次電池では，電極活物質粒子と イオン伝導材料である固体電解質が接触した界面において リチウムイオンが伝導し, 充放電が行われる. 従って, 電 極層内に活物質と電解質の固固接触界面を構築する必要があ る.これに加え, 正極層内の活物質と負極層内の活物質をつ なぐリチウムイオンの輸送経路と, 各電極層内の活物質と集 電体をつなぐ電子の輸送経路も形成する必要がある。しかし ながら，一般に，活物質粒子および固体電解質粒子はともに 粒子径が数 $\mu \mathrm{m}$ 以下の微粒子であり，粉体工学の観点からは 付着・凝集性が強い難流動性の粉体材料に分類される ${ }^{1)}$. そ のため,これらを沉用的な混合・分散プロセスで混合するだ けでは, 良好な固固接触界面とイオン・電子の輸送経路を構 築することは容易ではない（Fig. 1 (a))．加えて，電池全体 の容量を向上させるためには電極層中における活物質粒子の

* Corresponding author, E-mail: hnakamura@chemeng.osakafu-u.ac.jp
割合をできるだけ増やすことが必要となるが, 少量の固体電 解質を多量の活物質粒子表面に接触させることは，ますます 困難となる。この課題を解消するには，電極層を作製する前 に予め活物質粒子表面を固体電解質で被覆することが有効で ある（Fig. 1 (b)）。個々の活物質粒子を固体電解質で被覆す ることができれば，単一粒子スケールで固固接触界面を構築 することができる。この被覆粒子を用いて電極層を作製すれ ば，高い固固接触面積を実現することができる。しかしなが ら，これを実現するための粉体加工技術の開発が大きなボト ルネックとなっていた。 このような背景のもと, 我々は, 乾 式で電極活物質粒子を固体電解質粒子で被覆する技術（乾式 コーティング技術）を開発した ${ }^{2-5)}$. 本稿ではその成果の一部 をご紹介する．はじめに，乾式コーティング技術の基礎的概 念を概説する．次に，正極活物質粒子を硫化物固体電解質で 乾式コーティングした検討結果（得られたコアシェル型複合 粒子の特性と, この複合粒子から作製した全固体ハーフセル の性能）について紹介する. 


\section{2 乾式コーティングの基礎}

乾式コーティングとは，溶媒等を一切使用せず，装置内で 粒子に加えられる機械的エネルギーのみで大粒子の表面を粒 子径の小さな粒子で被覆する技術であるの). 乾式コーティン グの基礎となるのは，混合技術である．Fig. 2 に2成分粉体 の混合機構を模式的に示す，本図は，混合度（混合粉体の均 一性を表す指標）を混合時間に対して対数プロットしたもの である. Fig. 2 (a) は，等粒子径の粉体同士を混合する通常の 混合操作の場合を示す，混合初期には対流混合と呼ばれる巨 視的な粒子群の位置交換が行われる。次に，粒子群内の速度 分布によって生じる粒子相互の滑りや衝突，摚找羽根と容器 壁面間に扔いて生じる粒子群の圧縮と伸長などにより，粒子 群が次第に解砕され微視的な粒子群の位置交換が行われる.

この過程は，せん断混合として知られている．さらに混合操 作を進めると，充填状態や大さの違い，流れ方向のわずかな 速度差や粒子の自転運動に起因する粒子間での位置交換に よって局所的な混合が生じる。この過程は拡散混合として知 られている，通常の混合操作では，この状態が混合の最終状 態である。この最終状態は，巨視的には均一な混合状態とも 言えるが，微視的に見ると，異種粉体を構成する一次粒子の

(a) Conventional process

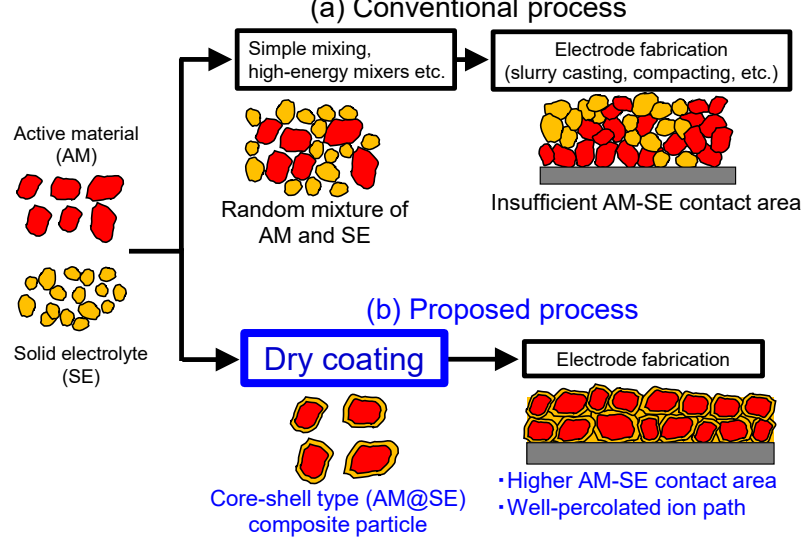

Fig. 1 The proposed dry coating process.

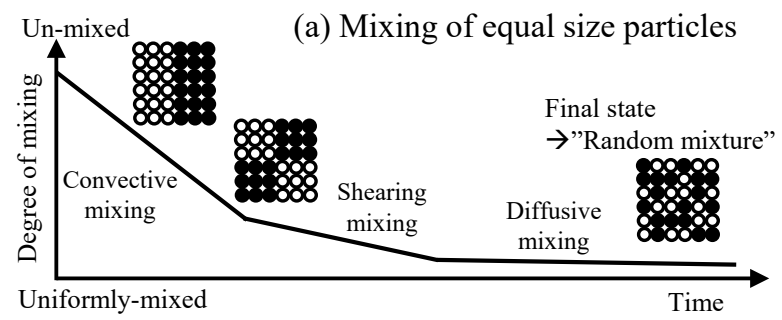

(b) Mixing of coarse and fine particles

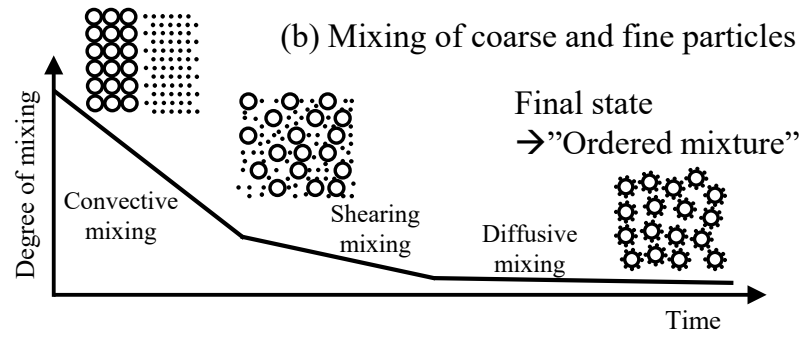

Fig. 2 Schematic of temporal change in the degree of powder mixing.
配置はランダムである。このことから，通常の混合操作で得 られる最終混合物はランダム混合物（Random mixture）と呼 ばれる。しかしながら，Fig. 2 (b) に示すように，異種粉体の 粒子径に顕著なサイズの違いがある場合（経験的には 10 倍 以上の粒子径比)，拡散混合物に強力な機械的エネルギーを 加え続けると，大粒子の表面が小粒子で被覆された混合状態 が達成される．この，構造化された混合状態状態は，規則混 合物（Ordered mixture）と呼ばれている7). Ordered mixtureが 形成される要因は，大粒子と小粒子間に作用する付着力と, 小粒子に作用する重力（慣性力）のバランスで説明できる,7) Ordered mixture に機械的エネルギーを加え続けると，大粒子 の表面に付着した小粒子は，大粒子表面に打ち込まれたり， 小粒子同士が融合して連続的な被膜を形成するなどにより， 小粒子は大粒子に固定化される場合もある．粉体工学の観点 からは，この Ordered mixture を形成する操作が乾式コーティ ングに相当する．乾式コーティングを達成するには，大粒子 と小粒子の粒子径比を予め制御することと, 強力な機械的工 ネルギーを粒子に効率良く加えることができる装置設計が重 要となる。

\section{3 正極活物質と硫化物イオン伝導材料の コアシェル型複合粒子の合成}

本研究で目標とした複合粒子の粒子設計は次の通りであ る. すなわち，正極活物質粒子の表面があらかじめ酸化物固 体電解質（例えば $\mathrm{LiNbO}_{3}$ などの材料．活物質と固体電解質 間の界面抵抗を下げる目的で被覆する必要がある $\left.{ }^{8)}\right)$ でコー ティングされたものをコア粒子とし，このコア粒子を破壊す ることなく, 硫化物固体電解質で均一に被覆したコアシェル 型の複合粒子（正極活物質@硫化物固体電解質コアシェル粒 子）の合成を目標とした.

Fig. 3 (a), (b) に乾式コーティングで用いた原料粒子の SEM 像を示す．正極活物質粒子には表面を $\mathrm{LiNbO}_{3}$ で予めコーティ ングされた $\mathrm{LiNbO}_{3}$-coated $\mathrm{LiNi}_{1 / 3} \mathrm{Co}_{13} \mathrm{Mn}_{1 / 3} \mathrm{O}_{2}$ (NCM, ALACSPRING，平均粒子径 $=5.4 \mu \mathrm{m}$, ) を用いた，硫化物固体電解 質には，典型的な材料である $\mathrm{Li}_{3} \mathrm{PS}_{4}$ (LPS, ALAC-SPRING) を用いた。用いたLPS はメカニカルミリングで合成した非 晶質の材料である. LPS は予め湿式粉砕して, 個数基準平均 径 $0.5 \mu \mathrm{m}$ まで微細化したものを用いた．Fig. 3 (c) に複合化 装置として用いた高速気流中衝撃装置（NHS，奈良機械製作 所）の模式図を示す. 装置は処理室, 高速回転するローター, および循環経路で主に構成されている。装置内に投入された 原料粒子は，高速回転するローターによって生じる高速気流 により速やかに気中分散され，循環経路を通じて処理室を出 入りする．この際，処理室内で衝撃力やせん断力などの機械 的外力を受け，その結果，乾式コーティングが進行する．実 際の乾式コーティングは以下の手順で行った。はじめに, 両 試料を乳鉢で混合し単純混合物 (simple mixture) を調製し た. そして, この単純混合物を高速気流中衝撃装置に投入し, 所定の条件で処理した，以降で紹介する検討では，NCM と LPS の配合割合は NCM:LPS $=85: 15 \mathrm{wt} \%$ とした，装置運転条 
(a)

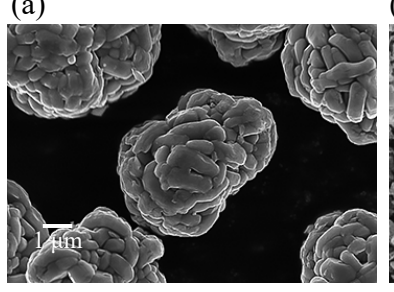

(b)
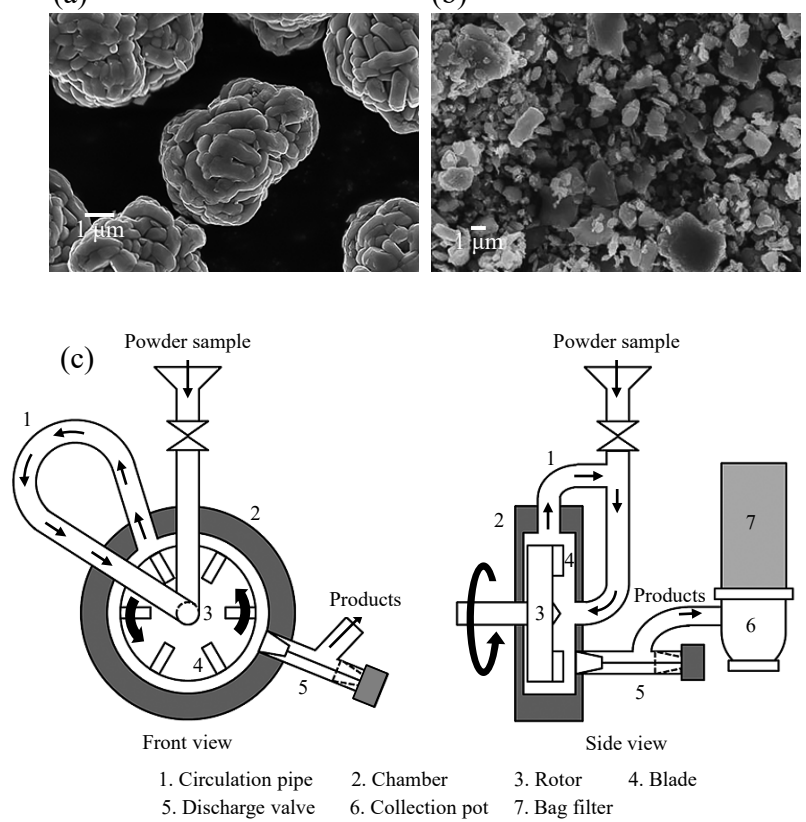

Fig. 3 Materials and equipment used in this study. SEM images of the (a) original $\mathrm{LiNi}_{1 / 3} \mathrm{Co}_{1 / 3} \mathrm{Mn}_{1 / 3} \mathrm{O}_{2}$ (NCM) and (b) $\mathrm{Li}_{3} \mathrm{PS}_{4}$ (LPS) particles. A schematic of the dry impact-blending device is shown in (c).

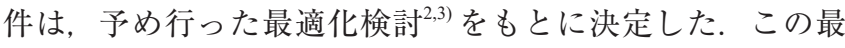
適条件に抢いては，処理時間は 5 分であり，極めて短時間で 乾式コーティング処理を行うことができる，なお，本検討で 用いた硫化物固体電解質は，大気中の微量な水分により分解 し，イオン伝導度が低下してしまうため，極低水分雾囲気で 扱う必要がある。 そのため，特別仕様のグローブボックス内 に高速気流中衝撃装置を設置して，すべての実験を極低水分 雾囲気（露点が約 $-80^{\circ} \mathrm{C}$ ) で行った.

Fig. 4 (a), (b)に，乳鉢混合で調製した単純混合物（乾式 コーティング前の試料）と，乾式コーティングで合成した粒 子のSEM像および元素マッピング像をそれぞれ示す。単純 混合物（Fig. 4 (a)）は，LPS 粒子が部分的に NCM 粒子表面 に付着しているものの, 使用した NCM 粒子に特有の表面構 造（アスペクト比の大きな矩形状の結晶粒凝集体に起因する 凹凸）が観察されたことから，NCM 粒子表面は部分的にし か被覆されなかった。一方，乾式コーティングで得られた粒 子では，NCM 粒子の表面に特有の凹凸が観察されず，滑ら かな表面が観察された。 また NCM 由来の Mn と LPS 由来の Sのマッピング像の位置が一致していた．Fig. 4 (c)に，乾式 コーティングした単一粒子断面の SEM 像を示す．NCM 粒子 (薄灰色）の表面はLPS 層（濃灰色）で均一に被覆されてお り，この条件では被覆層は打打上そ 0.1 から $0.2 \mu \mathrm{m}$ の厚みで あった。 以上の結果より, 狙いとしたNCM@LPS コアシェ ル粒子を合成することができた．Fig. 4 (d) に，各粉体の粒度 分布を示す．乾式コーティング後の複合粒子からは，LPS 粒 子に由来する $3 \mu \mathrm{m}$ 以下の微粒子が計測されなかった。これ より，ほとんどの LPS 粒子はNCM 粒子表面に付着・固定化 されたことも分かった，最後に，合成した乾式コーティン (a)
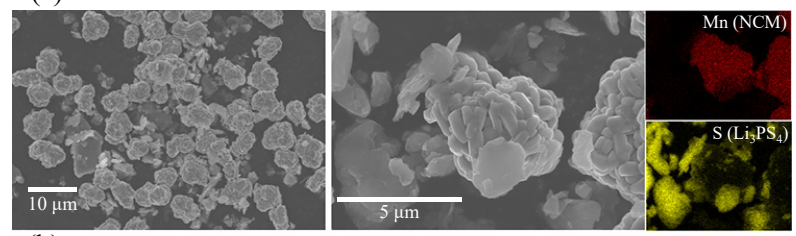

(b)
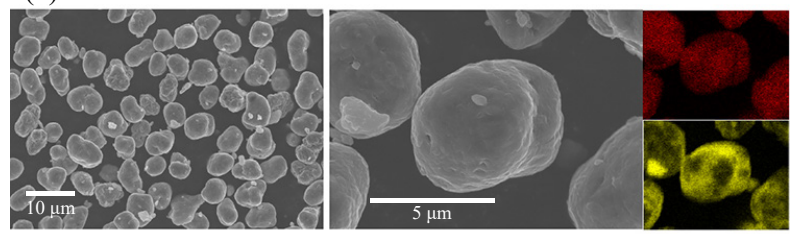

(c)
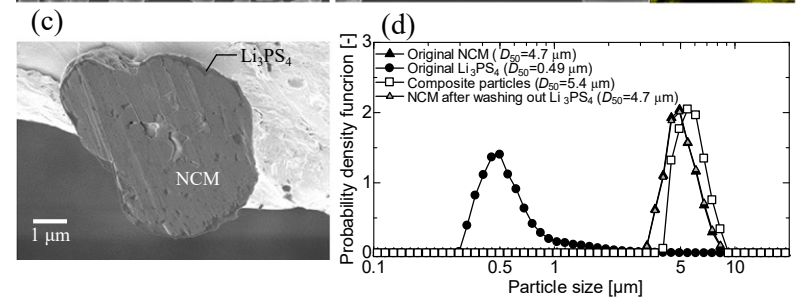

Fig. 4 SEM and EDX images of the (a) simple mixture prepared by mortar and pestle mixing and (b) composite particle prepared by dry coating. (c) Cross-section of the single composite particle. The light gray and dark gray regions correspond to $\mathrm{NCM}$ and $\mathrm{Li}_{3} \mathrm{PS}_{4}$, respectively. (d) Number based particle size distribution of each particle. $D_{50}$ represents the number based median diameter.

グ粒子をアルコールで洗浄し，被覆層の LPS を溶解させて 除去した後に得られた正極活物質の粒度分布を測定した結果 (Fig. 4 (d))，原料の正極活物質の粒度分布とほほ一致してい ており，正極活物質の摩耗や破壊はないことも確認できた。

以上の結果より，乾式コーティングを用いて，正極活物質粒 子の磨耗や破壊を起こすことなく，固体電解質で活物質粒子 表面が均一に被覆されたコアシェル型複合粒子を合成するこ とができた。

これまでに実施した種々の検討結果より，本研究の乾式 コーティングは次のメカニズムで進行すると考えられる ${ }^{2,3,5)}$. はじめに, 粉体試料を前混合することによって, 正極活物質 表面に固体電解質が部分的に付着する. 次に, 乾式コーティ ング処理を行うことで, 粉体試料が強い機械的外力を受け, 固体電解質の塑性変形及び合一化が生じる。これは, コア粒 子である正極活物質（此較的硬く，脆性材料）と被覆粒子で ある硫化物固体電解質（比較的柔らかく, 加圧のみで粒子同 士が合一して粒界が消失 $\left.{ }^{109}\right)$ の機械的特性が大きく異なるこ とに起因する。そその後, 固体電解質の塑性変形及び合一化が さらに進行し, 最終的に固体電解質が緻密な膜状の被覆層に なると考えられる。

\section{4 コアシェル型複合粒子から作製した全固体セルの 性能と構造}

コアシェル型複合粒子（NCM@LPS 粒子）が電池性能の 向上に寄与することを検証するため, 得られた乾式コーティ ング粒子を用いて圧粉ハーフセル（正極：NCM@LPS 粒子 /セパレータ： $\mathrm{Li}_{3} \mathrm{PS}_{4}$ ペレット/負極：Li-In合金箔，成型 


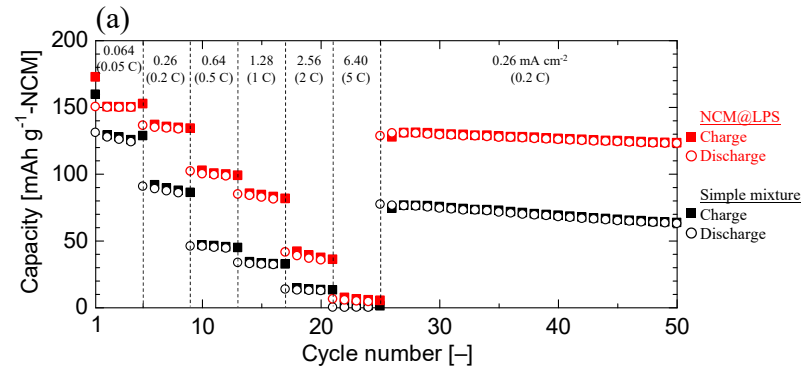

(b)
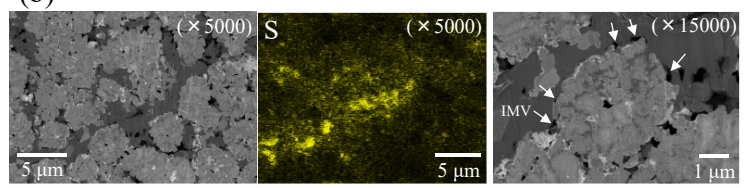

(c)
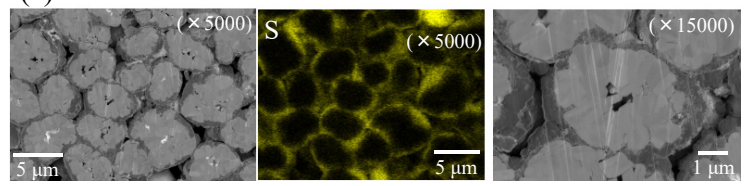

Fig. 5 Performance of the all-solid-state half-cells prepared with the NCM@LPS core-shell composite particles and simple mixture obtained via mortar and pestle mixing. (a) Rate capability and cycle performance at different discharge current densities (C rates). SEM and EDX images of the cross-sections of the composite cathodes prepared with the (a) simple mixture and (b) NCM@LPS core-shell particles. The light gray, dark gray, and black regions in the SEM images correspond to NCM, LPS, and voids, respectively. The white arrows indicate the interfacial microvoid (IMV) on the NCM surface.

圧 $360 \mathrm{MPa}$ ）を作製し充放電試験を行った ${ }^{5)}$. 比較のため,

NCM と LPS の含有割合を乾式コーティング品と同一にした 単純混合物（乳鉢混合で調製）を用いて，同様の圧粉ハーフ セルを作製し，評価を行った．Fig. 5 (a) に作製した各セルの サイクル特性を示す. NCM@LPS 粒子は, 単純混合物と比 較すると容量が顕著に増加した。特に, 高電流密度下 $(0.2 \mathrm{C}$ から $1.0 \mathrm{C})$ に扔ける性能を比較すると, 乾式コーティング を行うことで放電容量は約 2 倍まで向上した. Fig. 5 (b), (c) に，単純混合品㧍よびNCM@LPS 粒子から作製した正極層 断面のSEM 像及び元素マッピング像を示す。単純混合物か ら作製した電極層では（Fig. 5 (b)), 活物質粒子（薄灰色） が㠜集しており，固体電解質（濃灰色）とは部分的にしか接 触していなかった。 また，活物質粒子の表面を観察すると，

図中の矢印でしめすように，固体電解質との界面に微小空隙 (interfacial micro void, IMV と表記) が多く観察された.一方, NCM@LPS 粒子から作製したセルでは，活物質粒子が凝集 することなく，個々の活物質粒子表面が固体電解質で覆われ ていた，また，固体電解質との界面では微小空隙は観察され ず, 活物質と固体電解質の接触面積が飛躍的に大きい電極構 造を示した. 断面の 2 次元構造だけでなく, 電極層の 3 次元 構造もFIB-SEM を用いて把握し, 活物質 - 固体電解質の接 触率と, 電極層全体のリチウムイオンの有効伝導率を定量化 した，その結果, NCM@LPS 粒子から作製した電極層は単 純混合物から作製したものと比べて, 接触率は 1.3 倍, 有効 イオン伝導率は 1.48 倍向上していることも分かった
より, 固固接触界面が活物質粒子の 1 次粒子スケールで構築 されているNCM@LPS コアシェル型複合粒子を用いること で, 活物質と固体電解質の接触率が高く、リチウムイオンが 伝導しやすい電極構造を作製することができた，その結果， 全固体電池の性能が大きく向上した。

\section{5 おわりに}

乾式コーティングで電極活物質粒子をイオン伝導材料であ る固体電解質粒子で被覆する技術について紹介した，乾式 コーティング技術を用いて，正極活物質粒子の磨耗や破壊を 起こすことなく, 固体電解質で活物質粒子表面が均一に被覆 されたコアシェル型の複合粒子を合成することができた。こ のコアシェル型複合粒子から作製した電極は，高い活物質と 固体電解質の接触率と, 高いリチウムイオン有効伝導率を持 つ電極構造を有していた。この構造に起因して, コアシェル 型の複合粒子を用いることで全固体電池の性能が大きく向上 した.

開発した乾式コーティング技術は，処理時間がわずか数分 であり, 生産性にも優れている. また, 複合化装置も比較的 シンプルであり，スケールアップも容易に行えることから， 実用化への展開も大いに期待される. 学術的な観点からは, 電極層 3 次元構造の詳細な分析や, 充放電シミュレーション 解析などを組み合わせて, 複合粒子構造および電極層構造と 全固体電池性能の関係を明らかにすることで, 全固体電池性 能を決定づけている本質的な要因の解明に繋がることが期待 される。

\section{謝辞}

本研究はJST の ALCA-SPRINGの一環として実施した。一 連の研究は, 大阪府立大学綿野哲教授と共同で害施した。 ま た, 試料の評価・分析では大阪府立大学辰已砂昌弘教授, 林 晃敏教授, 作田敦助教, トヨ夕自動車斎藤俊哉博士, 産業技 術総合研究所倉谷健太郎博士のご協力を頂いた．記して謝意 を表します。

\section{文献}

1) D. Geldart: Powder Technol., 7 (1973) 285-292.

2) T. Kawaguchi, H. Nakamura, S. Watano: Powder Technol., 305 (2017) 241-249.

3) T. Kawaguchi, H. Nakamura, S. Watano: Powder Technol., 323 (2018) 581-587.

4) Watano, Nakamura, PCT/JP2017/29731 (2017)

5) H. Nakamura et al., T. Kawaguchi, T. Masuyama, A. Sakuda, T. Saito, K. Kuratani, S. Ohsaki, S. Watano: J. Power Sources, 448 (2020) 227579.

6) R. Pfeffer, R. N. Dave, D. Wei, M. Ramlakhan: Powder Technol., 117 (2001) 40-67.

7) J. A. Hersey: Powder Technol., 11 (1975) 41-44.

8) K. Takada: Solid State Ionics, 179 (2008) 1333-1337.

9) A. Sakuda, A. Hayashi, M. Tatsumisago: Sci. Rep., 3 (2013) 2261. 